\title{
Adaptation of Glucose Production and Gluconeogenesis to Diminishing Glucose Infusion in Preterm Infants at Varying Gestational Ages
}

\author{
ANNE A.M.W. VAN KEMPEN, JOHANNES A. ROMIJN, AN F.C. RUITER, \\ MARIËTTE T. ACKERMANS, ERIK ENDERT, J. HANS HOEKSTRA, JOHANNA H. KOK, AND \\ HANS P. SAUERWEIN \\ Metabolism Unit, Department of Endocrinology and Metabolism [A.A.M.W.v.K., J.A.R., A.F.C.R., M.T.A., \\ E.E., H.P.S.], Department of Neonatology and Department of Pediatrics, Emma Children's Hospital \\ [A.A.M.W.v.K., J.H.K.], and Department of Clinical Chemistry, Laboratory of Endocrinology [A.F.C.R., \\ M.T.A., E.E.], Academic Medical Center, Amsterdam; Department of Endocrinology, Leiden's University \\ Medical Center, Leiden [J.A.R.]; and Department of Pediatrics, Bosch Medicentrum, 's-Hertogenbosch
} [J.H.H], the Netherlands.

\begin{abstract}
In preterm infants low plasma glucose concentrations are frequently observed. We hypothesized that the infants' ability to adapt endogenous glucose production to diminishing exogenous supply is disturbed, but will improve with increasing gestational age. Glucose production rate and gluconeogenesis were measured using stable isotope techniques with $\left[6,6-{ }^{2} \mathrm{H}_{2}\right]$ glucose and $\left[2-{ }^{13} \mathrm{C}\right]$ glycerol in 19 preterm infants $(10 \leq 30 \mathrm{wk}$ and nine $>30$ wk gestational age) on d $5.0 \pm 1.4$ of life. Exogenous glucose was administered at a rate of $33 \mu \mathrm{mol} \cdot \mathrm{kg}^{-1} \cdot \mathrm{min}^{-1}$ followed by $22 \mu \mathrm{mol} \cdot \mathrm{kg}^{-1} \cdot \mathrm{min}^{-1}$. In the first $2 \mathrm{~h}$ after the decrease in exogenous supply, plasma glucose concentration declined comparably in both groups: $\leq 30 \mathrm{wk}$, from $4.3 \pm 1.2$ to $3.2 \pm 0.9$ $\mathrm{mM} ;>30 \mathrm{wk}$, from $3.7 \pm 0.7$ to $3.0 \pm 0.6 \mathrm{mM}$. Thereafter, only in infants $>30 \mathrm{wk}$ an increase was observed, to $3.4 \pm 0.8 \mathrm{mM}$. Glucose production rate increased comparably in both groups: $\leq 30 \mathrm{wk}$, from $6.0 \pm 4.1$ to $8.8 \pm 3.4 \mu \mathrm{mol} \cdot \mathrm{kg}^{-1} \cdot \mathrm{min}^{-1} ;>30$ wk, from $7.8 \pm 4.6$ to $11.6 \pm 5.2 \mu \mathrm{mol} \cdot \mathrm{kg}^{-1} \cdot \mathrm{min}^{-1}$. This increase was equivalent to approximately $30 \%$ of the decline in exogenous glucose. Gluconeogenesis increased comparably in
\end{abstract}

\section{ABSTRACT}

both groups: $<30 \mathrm{wk}$, from $3.2 \pm 1.2$ to $4.5 \pm 1.3$ $\mu \mathrm{mol} \cdot \mathrm{kg}^{-1} \cdot \mathrm{min}^{-1}$; >30 wk, from $4.3 \pm 1.9$ to $6.8 \pm 2.9$ $\mu \mathrm{mol} \cdot \mathrm{kg}^{-1} \cdot \mathrm{min}^{-1}$. We conclude that preterm infants can only partly compensate a decline in exogenous glucose supply by increasing endogenous glucose production rate, probably because of limitations in the final common pathway of intracellular glucose metabolism (i.e. glucose-6-phosphatase). The ability to maintain the plasma glucose concentration after a decrease in exogenous supply is better preserved in infants $>30 \mathrm{wk}$ owing to more efficient adaptation of peripheral glucose utilization. (Pediatr Res 53: 628-634, 2003)

$\quad$ Abbreviations
AGA, appropriate for gestational age
CI, confidence interval
GPR, (endogenous) glucose production rate
MIDA, mass isotopomer distribution analysis
Ra, rate of appearance
SGA, small for gestational age

A low plasma glucose concentration is frequently found in preterm infants, particularly during the first postnatal days, and may lead to serious short-term and long-term complications. The incidence is inversely related to declining gestational age and birth weight (1-3). Therefore, preterm infants routinely receive enteral feedings or i.v. glucose shortly after birth. Despite this policy, the incidence of hypoglycemia-defined as a plasma glucose concentration $<2.6 \mathrm{mM}$ - is still approx-

Received May 8, 2001; acccepted August 27, 2002.

Correspondence: Anne A.M.W. van Kempen, M.D., Department of Neonatology, H3-213, Emma Children's Hospital AMC, P.O. Box 22660, 1100 DD Amsterdam, The Netherlands; e-mail: A.vanKempen@amc.uva.nl

DOI: 10.1203/01.PDR.0000054733.13366.AF imately $20 \%$ in our neonatal intensive care unit, a referral unit for infants $\leq 32 \mathrm{wk}$ gestational age. The high risk of hypoglycemia may be related to limited substrate stores, a high brain-to-body weight ratio, and immature enzyme systems (4-6).

The pathophysiology of low plasma glucose concentrations in otherwise healthy preterm infants is not completely understood because of lack of sufficient data on glucose kinetics. Endogenous GPR in preterm infants of various gestational ages was measured under different circumstances (6-18). In most studies glucose was supplied at varying rates, showing that endogenous glucose production is almost completely suppressed during exogenous infusion rates higher than 7.5 
$\mathrm{mg} \cdot \mathrm{kg}^{-1} \cdot \mathrm{min}^{-1}$ in preterm infants, and $5.5 \mathrm{mg} \cdot \mathrm{kg}^{-1} \cdot \mathrm{min}^{-1}$ in term infants $(7,8,10-18)$. Because glucose supply (endogenous plus exogenous) equals glucose disposal during steadystate conditions, these data suggest that in preterm infants glucose requirements are approximately $7.5 \mathrm{mg} \cdot \mathrm{kg}^{-1} \cdot \mathrm{min}^{-1}$ and in term infants, $5.5 \mathrm{mg} \cdot \mathrm{kg}^{-1} \cdot \mathrm{min}^{-1}$.

Basal GPR without exogenous glucose supply varies from 3.0 to $5.5 \mathrm{mg} \cdot \mathrm{kg}^{-1} \cdot \mathrm{min}^{-1}$ in preterm infants, measured 3 to $6 \mathrm{~h}$ after the last feed $(6,7,9,10)$. These data are not different from those measured in full-term infants $(6,7,9,10,19-21)$. However, because of the supposedly higher glucose requirements in preterm infants, basal glucose production covers only 40 to $70 \%$ of their requirements, compared with 60 to $100 \%$ in term infants.

Endogenous glucose production is derived from gluconeogenesis and glycogenolysis. Therefore, low production rates can be caused by limitations in gluconeogenesis, glycogenolysis, or both. Gluconeogenesis has been measured in preterm infants $<30 \mathrm{wk}$ gestational age with stable isotope techniques in a single study (22). In that study, $72 \%$ of endogenous glucose production was derived from gluconeogenesis. In adults after an overnight fast gluconeogenesis contributes approximately 40 to $60 \%$ to endogenous glucose production (23-25).

From a clinical perspective the ability to increase glucose production to fully balance a decrease in exogenous glucose administration is an important defense mechanism against hypoglycemia. In adults, a decline in exogenous glucose supply below a certain level is fully compensated by an increase in endogenous production (26). Similar studies have not been performed in preterm infants. To elucidate the pathophysiology of glucose kinetics in preterm infants further, we designed a study to evaluate whether a decrease in glucose infusion rate below the range that represents the glucose requirements of these infants (see above) is fully compensated by an increase in endogenous glucose production. The second aim was to explore potential differences in the adaptive response between infants $\leq 30 \mathrm{wk}$ and infants $>30 \mathrm{wk}$ gestational age. To answer these questions we measured the rates of endogenous glucose production and gluconeogenesis with the stable isotope dilution technique and MIDA in 19 preterm infants during two rates of glucose infusion. In adults the adaptation to fasting is an established model to achieve better understanding of the pathophysiology of metabolic processes. In preterm infants prolonged fasting is ethically not acceptable because of the high risk of hypoglycemia. We therefore modified the fasting study design and evaluated the changes in glucose metabolism in response to a decline from a moderate to a low glucose infusion rate, instead of complete fasting.

Because glucose kinetics may be influenced by several hormones (insulin, cortisol, glucagon, catecholamines), gluconeogenic precursors (alanine), and FFA, these were also measured during the study. We hypothesized that preterm infants are not able to fully balance a decrease in exogenous glucose supply by an increase in endogenous production and that the youngest age group will be the most compromised, without significant differences in hormonal status or precursor supply.

\section{METHODS}

Patients. Preterm infants were recruited from the Neonatal Intensive Care Unit at the Emma Children's Hospital Academic Medical Center, Amsterdam, and Neonatal High Care Unit at the Bosch Medicentrum, 's-Hertogenbosch, the Netherlands. Preterm infants with a gestational age of 26-30 and 31-36 completed weeks were eligible for the study. We included infants with a postnatal age between 1 and $8 \mathrm{~d}$, because the incidence of low plasma glucose concentrations is the highest in the first postnatal week. Exclusion criteria were severe hypoglycemia (for ethical considerations and necessity of high rates of glucose infusion), birth weight $>90$ th percentile for gestational age (27), sepsis, severe perinatal asphyxia (5-min Apgar score $<7$ ), congenital malformations, severe respiratory distress, need of vasopressor support, and maternal diabetes or glucose intolerance. Written informed consent by the parents was obtained in all cases. This study was approved by the Medical Ethical Committee of the Academic Medical Center in Amsterdam and Bosch Medicentrum in 's-Hertogenbosch, the Netherlands.

Study design. The study design is shown in Figure 1. Before the study all infants received enteral or parenteral nutrition (or a combination) according to the nutrition protocol in our ward. Enteral and parenteral nutrition were discontinued $6 \mathrm{~h}$ before the study and replaced by i.v. glucose supply (unlabeled) at a rate of $33 \mu \mathrm{mol} \cdot \mathrm{kg}^{-1} \cdot \mathrm{min}^{-1}\left(6 \mathrm{mg} \cdot \mathrm{kg}^{-1} \cdot \mathrm{min}^{-1}\right)$. The fluid intake was kept at the level prescribed by the attending clinician, according to the protocol in our ward, and was not changed during the study. Infusions were administered through an i.v. (peripheral or central venous) catheter, previously introduced for clinical reasons. Blood samples were drawn from a second i.v. catheter in the opposite limb or, if present, from an intraarterial line.

After obtaining a baseline blood sample at $\mathrm{t}=-180 \mathrm{~min}$ $(0800 \mathrm{~h})$ for determination of background isotopic abundance and plasma glucose concentration, a primed $(80 \mu \mathrm{mol} / \mathrm{kg}$ body weight), continuous $\left(0.9 \mu \mathrm{mol} \cdot \mathrm{kg}^{-1} \cdot \mathrm{min}^{-1}\right)$ infusion of $[6,6-$ ${ }^{2} \mathrm{H}_{2}$ ]glucose was started on top of the cold glucose infusion, to measure glucose production. $\left[6,6-{ }^{2} \mathrm{H}_{2}\right]$ glucose $(99 \%$ enriched, Cambridge Isotopes, Cambridge MA, U.S.A.), dissolved in sterile isotonic saline and sterilized by passage of the solution through a Millipore filter (size $0.2 \mu \mathrm{m}$; Minisart, Sartorius AG, Göttingen, Germany) was administered by a calibrated syringe pump (Perfusor fm, Braun, Melsungen AG, Germany). Simultaneously, a primed $(272 \mu \mathrm{mol} / \mathrm{kg}$ body weight), continuous [4.53 $\mu \mathrm{mol} \cdot \mathrm{kg}^{-1} \cdot \mathrm{min}^{-1}$ (approximately $2.25 \mu \mathrm{mol} \cdot \mathrm{kg}^{-1} \cdot \mathrm{min}^{-1}$



Figure 1. Study design. Arrows indicate blood sampling times (t $=-180$, $-15,0,+15,+165,+180$, and $+195 \mathrm{~min})$. 
glucose equivalents)] infusion of $\left[2-{ }^{13} \mathrm{C}\right]$ glycerol $(99 \%$ enriched, Cambridge Isotopes) was started at $\mathrm{t}=-180 \mathrm{~min}$ on top of the cold glucose infusion, to measure fractional gluconeogenesis. Unlabeled glucose was continued at a rate of 33 $\mu \mathrm{mol} \cdot \mathrm{kg}^{-1} \cdot \mathrm{min}^{-1}\left(6 \mathrm{mg} \cdot \mathrm{kg}^{-1} \cdot \mathrm{min}^{-1}\right)$.

After an equilibration period of $165 \mathrm{~min}$ of stable isotope infusion, three blood samples were collected at 15-min intervals $(t=-15,0$, and $15 \mathrm{~min})$ for the measurement of isotopic enrichments and plasma glucose concentration. Subsequently, at $\mathrm{t}=15 \mathrm{~min}$, unlabeled glucose supply was diminished to 22 $\mu \mathrm{mol} \cdot \mathrm{kg}^{-1} \cdot \mathrm{min}^{-1}\left(4 \mathrm{mg} \cdot \mathrm{kg}^{-1} \cdot \mathrm{min}^{-1}\right)$. Three blood samples were collected again at 15-min intervals $(t=165,180$, and 195 min) for isotopic enrichment and plasma glucose determination. At $\mathrm{t}=0$ and $\mathrm{t}=180 \mathrm{~min}$, blood was also collected for determination of insulin, glucagon, cortisol, epinephrine, norepinephrine, alanine, and FFA. Plasma glucose concentration was measured at least once per hour during the study period.

Assays. All measurements were performed in duplicate, except for the MIDA samples, and all samples of individual newborns were analyzed in the same run.

Plasma glucose concentration was measured by the glucose oxidase method (Beckman Glucose Analyzer, Beckman Instruments Inc., Mijdrecht, the Netherlands).

Gas chromatography/mass spectrometry (GC/MS) analyses were performed with a model 5890 Series II gas chromatograph coupled to a model 5989 A mass spectrometer (Hewlett Packard, Palo Alto, CA, U.S.A.). Sample preparation and measurement of $\left[{ }^{2} \mathrm{H}\right]$ and singly and doubly $\left[{ }^{13} \mathrm{C}\right]$-labeled glucose using a combination of $\left[6,6-{ }^{2} \mathrm{H}_{2}\right]$ glucose and $\left[2-{ }^{13} \mathrm{C}\right]$ glycerol for the MIDA technique have been described in detail by our group previously $(25,28)$.

Insulin levels were measured using a radio-immuno-assay (Pharmacia Diagnostics AB, Uppsala, Sweden). Glucagon levels were also determined with a RIA (Linco Research Inc., St. Charles, MO, U.S.A.). Cortisol levels were measured with an ELISA on an Immulite analyzer (DPC, Los Angeles, CA, U.S.A.). Catecholamines were determined with HPLC with fluorescence detection using $\alpha$-methyl-norepinephrine as internal standard. Alanine levels were measured with an enzymic micromethod (29). FFA levels were determined enzymatically using a NEFAC kit (WAKO Chemicals Gmbh, Neuss, Germany).

Calculations. Ra of glucose was calculated by the isotope dilution technique from the $\left[6,6-{ }^{2} \mathrm{H}_{2}\right]$ enrichment of glucose, using calculations for steady-state kinetics, adapted for the use of stable isotopes (30): $\mathrm{Ra}=\left(\mathrm{E}_{\mathrm{i}} / \mathrm{E}_{\mathrm{p}}\right) \times \mathrm{I}$, where $\mathrm{E}_{\mathrm{i}}$ and $\mathrm{E}_{\mathrm{p}}$ are the $\left[6,6-{ }^{2} \mathrm{H}_{2}\right]$ enrichments of the infusate and plasma, respectively, and $\mathrm{I}$ is the infusion rate of $\left[6,6-{ }^{2} \mathrm{H}_{2}\right]$ glucose. To determine endogenous GPR, exogenously infused glucose was subtracted from glucose Ra.

Precursor pool enrichment (p) and fractional gluconeogenesis (f) were calculated from the mass isotopomer distribution pattern of unlabeled and singly and doubly labeled glucose derived from $\left[2-{ }^{13} \mathrm{C}\right]$ glycerol as described by Hellerstein and Neese (31) and Neese et al. (32). Absolute rate of gluconeogenesis is calculated as the product of $\mathrm{f}$ times glucose Ra. Gluconeogenesis as a fraction of GPR is calculated as the absolute rate of gluconeogenesis divided by GPR.
Statistics. Data are reported as mean $\pm \mathrm{SD}$, unless otherwise stated. Analysis of repeated measurements was used to investigate the changes in plasma glucose concentration (proc mixed of SAS 6.12, SAS Institute Inc, Cary, NC, U.S.A.). Data within groups were analyzed by the paired samples $t$ test, with each infant serving as his or her own control. For the changes in the variables of glucose kinetics, mean differences and $95 \%$ CI are given. Data between groups were analyzed by the MannWhitney rank sum test. Statistical significance was set at $p<$ 0.05 .

\section{RESULTS}

Clinical data. The clinical characteristics of the infants are shown in Table 1. A total of 19 preterm infants (eight girls) were studied between the third and eighth day of life. Three infants were ventilated with mild ventilatory settings (two were $\leq 30 \mathrm{wk}$ gestational age) and received morphine for sedation, consistent with the routines in our ward. All infants were clinically stable and had normal body temperature and normal acid-base status with normal oxygen saturation levels. Thirteen infants received antibiotics, but none had positive blood cultures or clinical signs of infection. In addition, there were no differences between infants born to mothers treated with antenatal steroids and those born to untreated mothers. SGA infants [birth weight $<10$ th percentile (27)] showed no differences in any of the variables of glucose kinetics compared with AGA infants.

Glucose kinetics. Steady-state enrichments are shown in Table 2. During both study periods ( $\mathrm{t}=-15$ to $+15 \mathrm{~min}$ and $\mathrm{t}=165$ to $195 \mathrm{~min}$ ) approximate steady state-defined by a coefficient of variation of $<10 \%$-was reached. Therefore, for both study periods the mean values of the variables of glucose kinetics are presented: for study period 1 (exogenous glucose rate of approximately $33 \mu \mathrm{mol} \cdot \mathrm{kg}^{-1} \cdot \mathrm{min}^{-1}$ ), mean values from $\mathrm{t}=-15$ to $+15 \mathrm{~min}$, and for study period 2 (exogenous glucose rate of approximately $\left.22 \mu \mathrm{mol} \cdot \mathrm{kg}^{-1} \cdot \mathrm{min}^{-1}\right)$, mean values from $\mathrm{t}=165$ to $195 \mathrm{~min}$.

Glucose kinetics during i.v. glucose supply of 33 $\boldsymbol{\mu m o l} \cdot \mathbf{k g}^{-1} \cdot \mathbf{m i n}^{-1}$. Data are shown in Table 3. During glucose infusion at a rate of $33 \mu \mathrm{mol} \cdot \mathrm{kg}^{-1} \cdot \mathrm{min}^{-1}$, there were no significant differences between infants $\leq 30 \mathrm{wk}$ compared with infants $>30 \mathrm{wk}$ gestational age in glucose concentration, endogenous glucose production, or gluconeogenesis.

Adaptation to a decrease in i.v. glucose supply. In infants $\leq$ $30 \mathrm{wk}$ gestational age, the plasma glucose concentration declined significantly by $1.1 \mathrm{mM}(95 \% \mathrm{CI},-1.5$ to -0.6 ; from $4.3 \pm 1.2$ to $3.2 \pm 0.9 \mathrm{mM}$ ) during the first $2 \mathrm{~h}$ after diminution of i.v. glucose supply, and remained unchanged between the second and third hour: $3.2 \pm 0.9$ and $3.4 \pm 0.8 \mathrm{mM}$, respectively (mean difference, $+0.2 \mathrm{mM} ; 95 \% \mathrm{CI},-0.1$ to +0.5 ; Table 3 and Fig. 2). This change in plasma glucose concentration was associated with a decrease in total glucose appearance rate by $8.3 \mu \mathrm{mol} \cdot \mathrm{kg}^{-1} \cdot \mathrm{min}^{-1}(95 \% \mathrm{CI},-9.8$ to -6.7$)$ and an increase in endogenous GPR by $2.9 \mu \mathrm{mol} \cdot \mathrm{kg}^{-1} \cdot \mathrm{min}^{-1}(95 \%$ $\mathrm{CI},+1.6$ to +4.1 ), equivalent to $26 \pm 17 \%$ of the decline in exogenous glucose supply. The absolute rate of gluconeogenesis increased by $1.3 \mu \mathrm{mol} \cdot \mathrm{kg}^{-1} \cdot \mathrm{min}^{-1}(95 \% \mathrm{CI},+0.3$ to 
Table 1. Clinical characteristics

\begin{tabular}{|c|c|c|c|c|c|c|c|c|c|c|}
\hline \multirow[b]{2}{*}{ Subjects } & \multicolumn{5}{|c|}{ Subject characteristics } & \multicolumn{2}{|c|}{$\begin{array}{l}\text { Respiratory } \\
\text { support }\end{array}$} & \multicolumn{3}{|c|}{ Medication } \\
\hline & $\begin{array}{c}\text { Gestational } \\
\text { age } \\
\text { (wk) }\end{array}$ & $\begin{array}{l}\text { Birth } \\
\text { weight } \\
(\mathrm{g})\end{array}$ & $\begin{array}{l}\text { AGA or } \\
\text { SGA }\end{array}$ & $\begin{array}{l}\text { Postnatal age } \\
\text { (d) }\end{array}$ & Sex & $\begin{array}{l}\text { SIMV/ } \\
\text { HFOV/ } \\
\text { nCPAP }\end{array}$ & $\begin{array}{l}\mathrm{FiO}_{2} \\
(\%)\end{array}$ & $\begin{array}{l}\text { Antenatal } \\
\text { steroids }\end{array}$ & $\begin{array}{c}\text { Morphine } \\
\left(0.25 \mathrm{mg} \cdot \mathrm{kg}^{-1} \cdot \mathrm{d}^{-1}\right)\end{array}$ & $\begin{array}{c}\text { Caffeine } \\
\left(2-3 \mathrm{mg} \cdot \mathrm{kg}^{-1} \cdot \mathrm{d}^{-1}\right)\end{array}$ \\
\hline \multicolumn{11}{|l|}{$\leq 30 \mathrm{wk}$} \\
\hline 1 & $28 \% / 7$ & 1235 & AGA & 6 & M & - & 21 & yes & - & yes \\
\hline 4 & $29 \% / 7$ & 1190 & AGA & 5 & M & nCPAP & 35 & - & - & yes \\
\hline 5 & $303 / 7$ & 1390 & AGA & 6 & $\mathrm{~F}$ & nCPAP & 21 & yes & - & yes \\
\hline 6 & $26 \% / 7$ & 1025 & AGA & 5 & M & nCPAP & 21 & yes & - & yes \\
\hline 7 & $276 / 7$ & 1180 & AGA & 4 & M & nCPAP & 25 & yes & - & yes \\
\hline 8 & $301 / 7$ & 1005 & SGA & 5 & M & SIMV & 30 & yes & yes & - \\
\hline 9 & $305 / 7$ & 900 & SGA & 5 & $\mathrm{~F}$ & - & 21 & yes & - & yes \\
\hline \multicolumn{11}{|l|}{$>30 \mathrm{wk}$} \\
\hline 12 & $315 / 7$ & 1230 & AGA & 7 & $\mathrm{~F}$ & nCPAP & 25 & yes & - & yes \\
\hline 13 & $333 / 7$ & 2140 & AGA & 4 & $\mathrm{~F}$ & SIMV & 21 & yes & yes & - \\
\hline 14 & $34 \%$ & 2000 & AGA & 6 & M & - & 21 & - & - & yes \\
\hline 15 & $34 \% / 7$ & 1960 & AGA & 3 & $\mathrm{~F}$ & - & 21 & - & - & - \\
\hline 16 & $34 \%$ & 1960 & AGA & 3 & $\mathrm{~F}$ & nCPAP & 21 & yes & - & yes \\
\hline 17 & $316 / 7$ & 1110 & SGA & 3 & $\mathrm{M}$ & nCPAP & 25 & yes & - & yes \\
\hline 18 & $364 / 7$ & 2150 & SGA & 5 & M & - & 21 & - & - & - \\
\hline 19 & $335 / 7$ & 1310 & SGA & 7 & M & - & 21 & - & - & - \\
\hline Mean \pm SD & $33.6 \pm 1.5^{*}$ & $1710 \pm 414 *$ & & $4.9 \pm 1.7$ & & & & & & \\
\hline
\end{tabular}

Data are mean $\pm \mathrm{SD} . * p<0.01$ for comparison with infants $\leq 30 \mathrm{wk}$.

SIMV, synchronized intermittent mandatory ventilation; HFOV, high-frequency oscillatory ventilation; nCPAP, nasal continuous positive airway pressure.

Table 2. Steady state enrichments in glucose during infusion of $\left[6,6-{ }^{2} \mathrm{H}_{2}\right]$ glucose and $\left[2-{ }^{13} \mathrm{C}\right]$ glycerol and plasma glucose concentration

\begin{tabular}{|c|c|c|c|c|c|c|c|}
\hline & & \multicolumn{6}{|c|}{ Time (min) } \\
\hline & & \multicolumn{3}{|c|}{ Period 1} & \multicolumn{3}{|c|}{ Period 2} \\
\hline & & -15 & 0 & +15 & +165 & +180 & +195 \\
\hline$\left[6,6-{ }^{2} \mathrm{H}_{2}\right]$ glucose & $>30$ weeks & $2.14 \pm 0.27$ & $2.15 \pm 0.26$ & $2.11 \pm 0.29$ & $2.60 \pm 0.39$ & $2.57 \pm 0.41$ & $2.59 \pm 0.36$ \\
\hline \multirow[t]{2}{*}[{}^{13}\mathrm{C}_{1}]{ glucose } & $\leq 30$ weeks & $0.024 \pm 0.010$ & $0.023 \pm 0.011$ & $0.023 \pm 0.012$ & $0.035 \pm 0.017$ & $0.036 \pm 0.017$ & $0.037 \pm 0.017$ \\
\hline & $>30$ weeks & $0.023 \pm 0.008$ & $0.023 \pm 0.007$ & $0.023 \pm 0.007$ & $0.039 \pm 0.007$ & $0.041 \pm 0.006$ & $0.041 \pm 0.008$ \\
\hline \multirow{2}{*}{$\begin{array}{l}\text { Plasma glucose } \\
\text { concentration }\end{array}$} & $\leq 30$ weeks & $4.4 \pm 1.2$ & $4.2 \pm 1.2$ & $4.4 \pm 1.1$ & $3.5 \pm 0.7$ & $3.4 \pm 0.8$ & $3.5 \pm 0.7$ \\
\hline & $>30$ weeks & $3.7 \pm 0.6$ & $3.6 \pm 0.8$ & $3.8 \pm 0.7$ & $3.3 \pm 0.8$ & $3.4 \pm 0.8$ & $3.5 \pm 0.9$ \\
\hline
\end{tabular}

Data are mean $\pm \mathrm{SD}$.

+2.2 ). In infants $>30 \mathrm{wk}$ gestational age, the plasma glucose concentration declined significantly by $0.7 \mathrm{mM}(95 \% \mathrm{CI},-1.2$ to -0.2 ; from $3.7 \pm 0.7$ to $3.0 \pm 0.6 \mathrm{mM}$ ) during the first $2 \mathrm{~h}$ after diminution of i.v. glucose supply. This decline was followed by an increase by $0.4 \mathrm{mM}(95 \% \mathrm{CI},+0.1$ to +0.9$)$, to $3.4 \pm 0.8 \mathrm{mM}$ between the second and third hours (Fig. 2). The total rate of glucose appearance decreased by 7.0 $\mu \mathrm{mol} \cdot \mathrm{kg}^{-1} \cdot \mathrm{min}^{-1}(95 \% \mathrm{CI},-9.9$ to -4.2$)$, whereas endogenous GPR increased by $3.8 \mu \mathrm{mol} \cdot \mathrm{kg}^{-1} \cdot \mathrm{min}^{-1}(95 \% \mathrm{CI},+0.8$ to +6.8 ), equivalent to $35 \pm 36 \%$ of the decline in exogenous glucose supply. The absolute rate of gluconeogenesis increased by $2.4 \mu \mathrm{mol} \cdot \mathrm{kg}^{-1} \cdot \mathrm{min}^{-1}(95 \% \mathrm{CI},+0.5$ to +4.4$)$.

The changes in glucose production and gluconeogenesis were not significantly different between both groups.
Hormones, the gluconeogenic precursor alanine, and $\boldsymbol{F F A}$. The results are shown in Table 4. Because of a restriction in the amount of blood that could be taken, only measurements of insulin, cortisol, and FFA could be performed in all infants. In infants with a birth weight $>1000 \mathrm{~g}$, alanine was measured also. Blood for other hormones (glucagon and catecholamines) was collected only in infants $>1200 \mathrm{~g}$.

During i.v. glucose supply at a rate of $33 \mu \mathrm{mol} \cdot \mathrm{kg}^{-1} \cdot \mathrm{min}^{-1}$, plasma glucagon levels were significantly higher $(p=0.023)$ and plasma FFA levels were significantly lower $(p=0.014)$ in infants $\leq 30$ wk compared with infants $>30$ wk gestational age.

After diminishing the glucose infusion rate to 22 $\mu \mathrm{mol} \cdot \mathrm{kg}^{-1} \cdot \mathrm{min}^{-1}$, insulin levels declined significantly in both 
Table 3. Glucose kinetics during exogenous glucose supply at a rate of 33 versus $22 \mu \mathrm{mol} \cdot \mathrm{kg}^{-1} \cdot \mathrm{min}^{-1}$

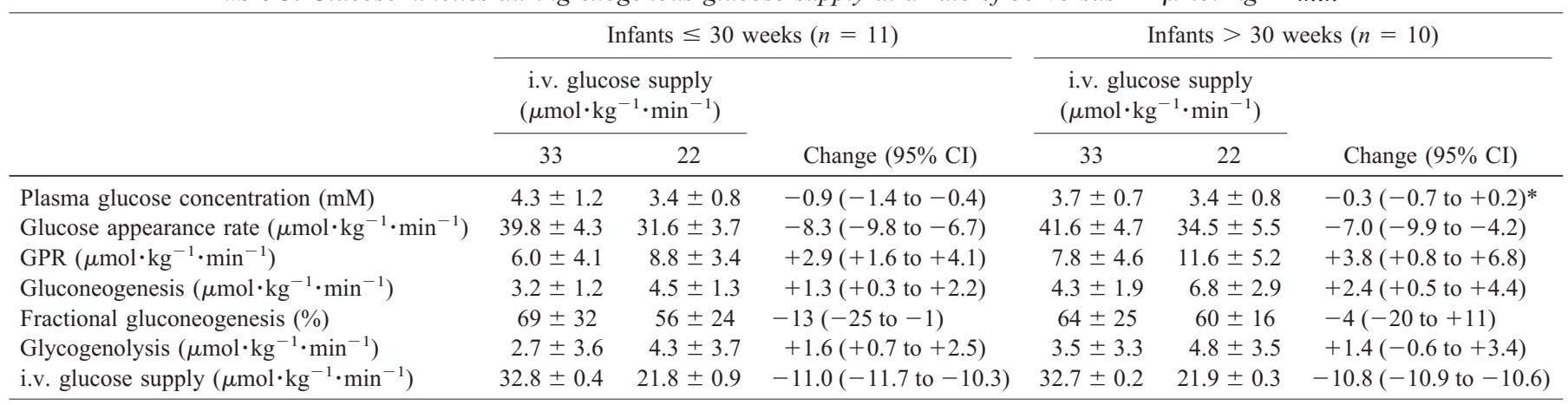

Data are mean $\pm \mathrm{SD}$, and mean differences $(95 \% \mathrm{CI})$.

$* p<0.05$ for comparison with infants $\leq 30 \mathrm{wk}$.

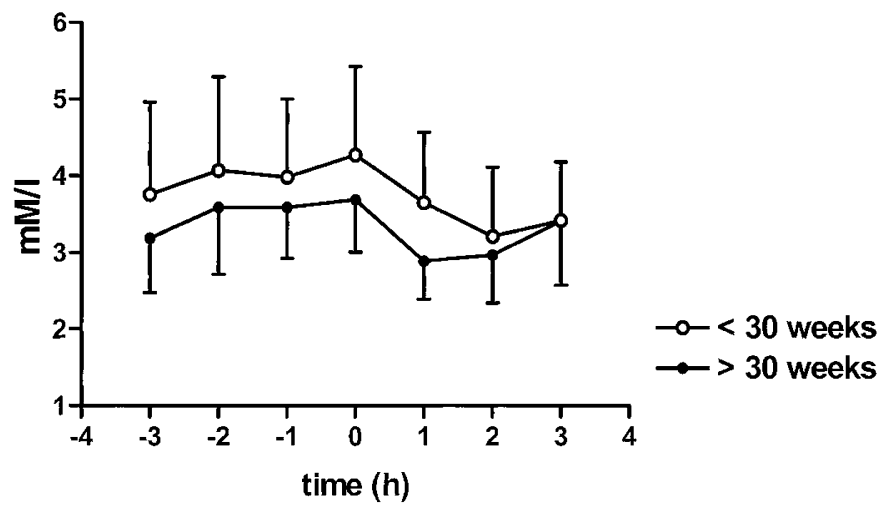

Figure 2. Plasma glucose concentration. Data are mean $\pm \mathrm{SD}$. In both groups plasma glucose concentration declined between $\mathrm{t}=0$ and $\mathrm{t}=2 \mathrm{~h}$. Thereafter, plasma glucose concentration increased only in infants $>30 \mathrm{wk}$.

groups: by $14 \mathrm{pM}(95 \% \mathrm{CI},-23$ to -5$)$ in infants $\leq 30 \mathrm{wk}$ and by $9 \mathrm{pM}(95 \% \mathrm{CI},-16$ to -2$)$ in infants $>30 \mathrm{wk}$ gestational age (NS between groups). Plasma alanine levels declined significantly only in infants $>30 \mathrm{wk}$, by $34 \mu \mathrm{M}(95 \% \mathrm{CI},-55$ to -13$)$.

\section{DISCUSSION}

Low plasma glucose concentrations are frequently found in preterm infants, the youngest infants being most compromised. This high risk of hypoglycemia may be related to small substrate stores, a high brain-to-body weight ratio, and immature enzyme systems (4-6), thereby disturbing the balance between glucose supply and requirements. Limited endogenous glucose production is attributed to restricted capacity for gluconeogenesis and glycogenolysis $(4,33-40)$. However, direct measurements of glucose production and glucose concentration were done mostly without or during a constant glucose infusion rate $(6-9,11,13,15,16)$, precluding conclusions about the adaptive capacity. In the present study we measured endogenous glucose production and gluconeogenesis as the potential adaptive capacity to counteract a decrease in the rate of exogenous glucose supply in preterm infants. We hypothesized that the ability to adapt to diminishing exogenous supply would be more compromised in very young infants $(\leq 30 \mathrm{wk}$ gestational age).

Our data clearly show the limited capacity of preterm infants in general to adapt their GPR to a decline in exogenous glucose supply within the 3-h study period. The decrease in exogenous glucose supply was only partly compensated by an increase in the production (approximately 30\%). This is in contrast to adults, in whom a decline in exogenous supply of glucose is fully compensated by an increase in production (26). We were not able to show a difference between infants $\leq 30 \mathrm{wk}$ and $>30$ wk gestational age with respect to their limited capability to increase glucose production. However, the age difference between the groups was relatively narrow. Most infants were between 28 and 30 wk gestational age in the $\leq 30$ wk group whereas most infants in the $>30$ wk group were between 33 and 35 wk. Although the changes in endogenous glucose production and gluconeogenesis were not significant between the groups, there was a trend toward better adaptation in the older group. We therefore cannot completely rule out the possibility that older preterm infants are better adapters than younger infants.

The limited capability to increase glucose production in the studied infants cannot be ascribed to an obvious lack of gluconeogenic capacity as gluconeogenesis covered approximately $62 \%$ of the glucose production. These data on the adaptation of glucose kinetics cannot be compared with data from the literature. However, the basal measurements in both groups obtained during glucose infusion at a rate of 33 $\mu \mathrm{mol} \cdot \mathrm{kg}^{-1} \cdot \mathrm{min}^{-1}$ were comparable to other studies using similar rates of i.v. glucose supply $(7,8,14,17)$.

Stable isotope steady-state was reached during the study as is shown by our results. Metabolic steady-state, however, could not be accomplished in our study because amino acids and a substantial amount of energy would have to be withheld for prolonged periods. We considered this unethical in our study population. Second but more important, our study was designed to evaluate short-term responses in glucose kinetics to changes in exogenous glucose supply. To put our results in perspective, a modification to the studies during short-term fasting in adults was chosen. In those studies metabolic steadystate is not reached either; but gradual changes in metabolism with time are found (41).

Both AGA and SGA infants were included in this study. The number of SGA and AGA infants was equal in both groups. We found no differences in any of the variables of glucose kinetics between AGA and SGA infants, and analyzed the data therefore in two groups divided by gestational age. When the 
Table 4. Glucoregulatory hormones, alanine, and FFA levels during exogenous glucose supply at a rate of 33 versus 22 $\mu \mathrm{mol} \cdot \mathrm{kg}^{-1} \cdot \mathrm{min}^{-1}$

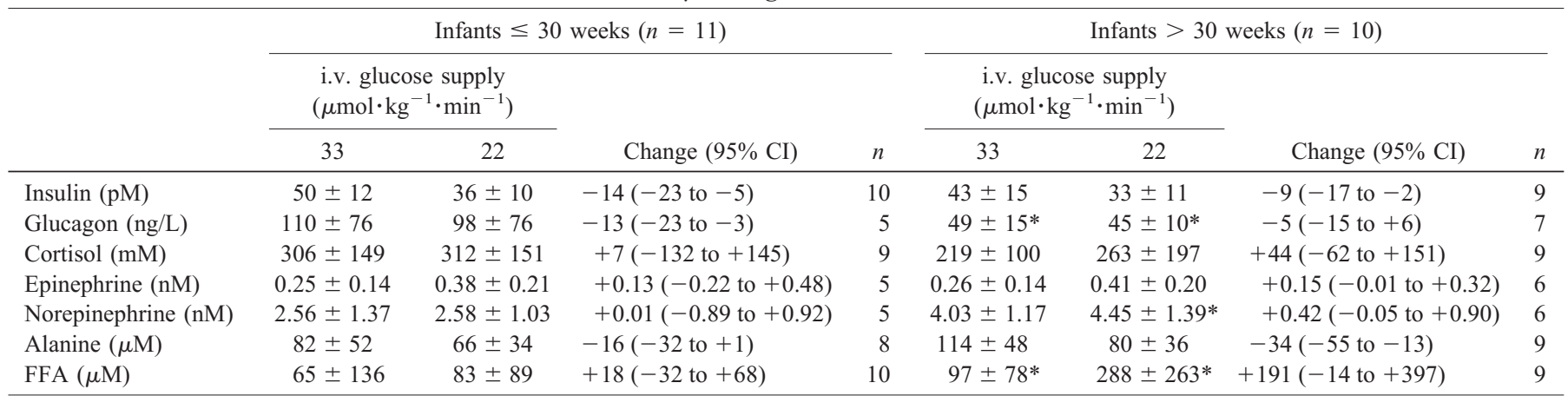

Data are mean \pm SD, and mean differences $(95 \% \mathrm{CI})$.

$* p<0.05$ for comparison with infants $\leq 30$ wk.

AGA and SGA infants were analyzed separately, still no differences were found between infants $\leq 30 \mathrm{wk}$ and infants $>30$ wk.

Both groups remained normoglycemic during the study, precluding conclusions about glucose kinetics during hypoglycemia. Furthermore, we cannot rule out that the exclusion of severely hypoglycemic infants has biased the results toward infants who already were better adapters. However, the study design precludes the inclusion of hypoglycemic infants, as it is ethically not acceptable to keep the plasma glucose concentration at low levels. In addition, it is not meaningful to include infants who are treated for severe hypoglycemia, because the necessary high rate of exogenous glucose supply might suppress endogenous glucose production.

Because no major differences in glucose production between infants $\leq 30 \mathrm{wk}$ and $>30 \mathrm{wk}$ were found, the slight differences in glucoregulatory hormones, alanine, and FFA levels between our groups seem to have no influence in this respect.

Direct measurement of gluconeogenesis in preterm infants was performed in only one study, by Sunehag et al. (22) in infants $<30$ wk gestational age during total parenteral nutrition containing $3 \mathrm{mg}$ glucose $\cdot \mathrm{kg}^{-1} \cdot \mathrm{min}^{-1}$. Gluconeogenesis was estimated by three techniques: MIDA using $\left[2-{ }^{13} \mathrm{C}\right] \mathrm{glyc}-$ erol or $\left[\mathrm{U}^{13} \mathrm{C}\right]$ glucose, and the ${ }^{2} \mathrm{H}_{2} \mathrm{O}$ technique with deuterium incorporation in $\mathrm{C} 6$ of glucose. In the latter method, using $\mathrm{C} 6$ instead of C5 enrichment, gluconeogenesis is underestimated because the contribution from glycerol to gluconeogenesis is not included and there is incomplete equilibration between body water and C6 of glucose $(23,24)$. However, measurement of deuterium incorporation into glucose $\mathrm{C} 5$ is not feasible in small infants because relatively large-volume blood samples are required. Gluconeogenesis estimated by $\left[\mathrm{U}^{13} \mathrm{C}\right]$ glucose and $\left[2-{ }^{13} \mathrm{C}\right]$ glycerol yielded similar results $(72 \%$ of endogenous glucose production, or an absolute rate of $7.6 \mu \mathrm{mol} \cdot \mathrm{kg}^{-1} \cdot \mathrm{min}^{-1}$ ) (22). In the present study, we measured gluconeogenesis by the MIDA technique using $\left[2-{ }^{13} \mathrm{C}\right]$ glycerol. Fractional gluconeogenesis was $56 \%$ in the infants $\leq 30$ wk gestational age in our study, compared with $72 \%$ in the infants of a comparable age group studied by Sunehag et al. (22). Their higher rate of gluconeogenesis can be explained by stimulation of gluconeogenesis by amino acids or lipid emulsion, administered as part of the parenteral nutrition. Another explanation for their higher fractional gluconeogenesis can be gradual depletion of glycogen stores, as a result of their study design (22).

The percentage of glucose derived from gluconeogenesis in the infants in our study is comparable to the fractional gluconeogenesis found in adults after an overnight fast. This suggests that the partial compensation for the decline in exogenous glucose supply is caused by limitations in the final common pathway of intracellular glucose metabolism (i.e. glucose-6-phosphatase), rather than a defect in either gluconeogenesis or glycogenolysis. This hypothesis is consistent with the in vitro findings of Hume et al. (42) of a low glucose-6phosphatase activity in hepatocytes of preterm infants. Glucose-6-phosphatase catalyzes the final step of hepatic gluconeogenesis and glycogenolysis. Low glucose-6-phosphatase activity will therefore result in a proportional effect on glucose derived from gluconeogenesis and glycogenolysis.

Although endogenous glucose production increased in both groups after reduction of exogenous supply, glucose availability (the sum of endogenous and exogenous glucose supply) to the tissues diminished by approximately $21 \%$ in infants $\leq 30$ wk and by approximately $17 \%$ in infants $>30$ wk gestational age. Despite this comparable decline, infants $>30$ wk were able to increase plasma glucose concentration after the initial decline, whereas the younger infants were not, suggesting a limited capacity to reduce peripheral glucose utilization in the younger group. This finding is in contrast with the response in healthy adults. They are able to maintain the plasma glucose concentration during a prolongation of the fast from 16 to $22 \mathrm{~h}$, despite a $20 \%$ decline in endogenous glucose production rate, caused by a concomitant decline in peripheral glucose uptake (41). The difference in response between the younger and the older preterm infants in our study can be explained by the differences at the end of the study in plasma norepinephrine or FFA as both are well-known inhibitors of peripheral glucose uptake $(43,44)$.

\section{CONCLUSIONS}

In conclusion, we showed that preterm infants could only partly compensate a decline in glucose infusion by increasing 
glucose production. The increase in endogenous glucose production and gluconeogenesis after a decrease in exogenous glucose supply was comparable between infants $\leq 30 \mathrm{wk}$ and $>30 \mathrm{wk}$ gestational age. The limitations in the increase in glucose production seem to be caused by limitations in the final common pathway of intracellular glucose metabolism (i.e. glucose-6-phosphatase), as there was a proportional increase in both the gluconeogenic and the glycogenolytic contribution to glucose production. The plasma glucose concentration declined initially in all infants, which was followed by an increase in infants $>30 \mathrm{wk}$. In contrast, in the younger infants the plasma glucose concentration remained unchanged in the last hour of the study, suggesting an additional insufficient adaptation of peripheral glucose utilization in this very young group.

Acknowledgments. The authors thank the participating children, their parents, and the medical and nursing staff of both neonatology departments for their cooperation. We thank G.J. Weverling, Ph.D., Department of Clinical Epidemiology and Biostatistics, Academic Medical Center, Amsterdam, for his help with the statistical analysis.

\section{REFERENCES}

1. Lubchenco LO, Bard H 1971 Incidence of hypoglycemia in newborn infants classified by birth weight and gestational age. Pediatrics 47:831-838

2. De Leeuw R, de Vries IJ 1976 Hypoglycemia in small-for-dates newborn infants. Pediatrics 58:18-22

3. Cornblath M, Schwartz R 1991 Disorders of carbohydrate metabolism in infancy. Blackwell Scientific Publications, Boston, pp 55-123

4. Shelley HJ 1961 Glycogen reserves and their changes at birth and in anoxia. Br Med Bull 17:137-143

5. Cowett RM 1998 Principles of Perinatal-Neonatal Metabolism. Springer Verlag, New York, pp 701-706, 1154-1155

6. Bier DM, Leake RD, Haymond MW, Arnold KJ, Gruenke LD, Sperling MA, Kipnis DM 1977 Measurement of "true" glucose production rates in infancy and childhood with 6,6-dideuteroglucose. Diabetes 26:1016-1023

7. Cowett RM, Oh W, Schwartz R 1983 Persistent glucose production during glucose infusion in the neonate. J Clin Invest 71:467-475

8. Cowett RM, Susa JB, Oh W, Schwartz R 1984 Glucose kinetics in glucose-infused small for gestational age infants. Pediatr Res 18:74-79

9. Cowett RM, Wolfe RR 1991 Glucose and lactate kinetics in the neonate J Dev Physiol 16:341-347

10. Kalhan SC, Oliven A, King KC, Lucero C 1986 Role of glucose in the regulation of endogenous glucose production in the human newborn. Pediatr Res 20:49-52

11. Baarsma R, Chapman TE, van Asselt WA, Berger R, Okken A 1990 Glucose kinetics in preterm and near term small-for-gestational age newborn infants. In: Chapman TE, Berger R, Reijngoud D-J, Okken A (eds) Stable Isotopes in Pediatric Nutritional and Metabolic Research. Intercept Ltd, Andover, U.K., pp 123-132

12. Baarsma R, Reijngoud D-J, Berger R, Okken A 1991 Response of endogenous glucose production (EGPR) to a change in blood glucose (BG) level in low birth weight (LBW) infants on the first day of life. Pediatr Res 30:641 [abstr]

13. Lafeber HN, Sulkers EJ, Chapman TE, Sauer PJJ 1990 Glucose production and oxidation in preterm infants during total parenteral nutrition. Pediatr Res 28:153-157

14. Hertz DE, Karn CA, Liu YM, Liechty EA, Denne SC 1993 Intravenous glucose suppresses glucose production but not proteolysis in extremely premature newborns. J Clin Invest 92:1752-1758

15. Van Goudoever JB, Sulkers EJ, Chapman TE, Carnielli VP, Efstatopoulos T, Degenhart HJ, Sauer PJ 1993 Glucose kinetics and glucoregulatory hormone levels in ventilated preterm infants on the first day of life. Pediatr Res 33:583-589
16. Tyrala EE, Chen X, Boden G 1994 Glucose metabolism in the infant weighing less than 1100 grams. J Pediatr 125:283-287

17. Sunehag A, Gustafsson J, Ewald U 1994 Very immature infants $(\leq 30 \mathrm{wk})$ respond to glucose infusion with incomplete suppression of glucose production. Pediatr Res 36:550-555

18. Sunehag A, Ewald U, Larsson A, Gustafsson J 1993 Glucose production rate in extremely immature neonates $(<28$ weeks) studied by use of deuterated glucose. Pediatr Res 33:97-100

19. Kalhan SC, Savin SM, Adam PAJ 1976 Measurement of glucose turnover in the human newborn with glucose-1 $1{ }^{13} \mathrm{C}$. J Clin Endocrinol Metab 43:704-707

20. Kalhan SC, Bier DM, Savin SM, Adam PAJ 1980 Estimation of glucose turnover and ${ }^{13} \mathrm{C}$ recycling in the human newborn by simultaneous $\left[1-{ }^{13} \mathrm{C}\right]$ glucose and $[6,6-$ ${ }^{2} \mathrm{H}_{2}$ ]glucose tracers. J Clin Endocrinol Metab 50:456-460

21. Denne SC, Kalhan SC 1986 Glucose carbon recycling and oxidation in human newborns. Am J Physiol 251:E71-E77

22. Sunehag A, Haymond MW, Schanler RJ, Reeds PJ, Bier DM 1999 Gluconeogenesis in very low birth weight infants receiving total parenteral nutrition. Diabetes 48:791800

23. Landau BR, Wahren J, Chandramouli V, Schumann WC, Ekberg K, Kalhan SC 1995 Use of ${ }^{2} \mathrm{H}_{2} \mathrm{O}$ for estimating rates of gluconeogenesis. J Clin Invest 95:172-178

24. Landau BR, Wahren J, Chandramouli V, Schumann WC, Ekberg K, Kalhan SC 1996 Contributions of gluconeogenesis to glucose production in the fasted state. J Clin Invest 98:378-385

25. Ackermans MT, Pereira Arias AM, Bisschop PH, Endert E, Sauerwein HP, Romijn JA 2001 Rates of gluconeogenesis in healthy men measured with ${ }^{2} \mathrm{H}_{2} \mathrm{O}$ are higher than measured with $\left[2-{ }^{13} \mathrm{C}\right]$ glycerol. J Clin Endocrinol Metab 86:2220-2226

26. Wolfe RR, Allsop JR, Burke JF 1979 Glucose metabolism in man: responses to intravenous glucose infusion. Metabolism 28:210-220

27. Kloosterman GJ 1970 On intrauterine growth. Int J Gynaecol Obstet 8:895-912

28. Dekker E, Hellerstein MK, Romijn JA, Neese RA, Peshu N, Endert E, Marsh K, Sauerwein HP 1997 Glucose homeostasis in children with falciparum malaria: precursor supply limits gluconeogenesis and glucose production. J Clin Endocrinol Metab 82:2514-2521

29. Schutgens RBH, Tjoe Awie C, Beemer FA, Berntssen WJM 1977 Rapid enzymic micromethod for the quantitative determination of $\mathrm{L}(+)$ alanine in blood and urine. Clin Chim Acta 80:1-5

30. Wolfe RR 1992 Calculations of substrate kinetics: single pool model. In: Wolfe RR (ed) Radioactive and Stable Isotope Tracers in Biomedicine. Principles and Practice of Kinetic Analysis. Wiley-Liss, New York, pp 119-144

31. Hellerstein MK, Neese RA 1992 Mass isotopomer distribution analysis: a technique for measuring biosynthesis and turnover of polymers. Am J Physiol 263:E988-E1001

32. Neese RA, Schwartz J-M, Faix D, Turner S, Letscher A, Vu D, Hellerstein MK 1995 Gluconeogenesis and intrahepatic triose phosphate flux in response to fasting or substrate loads. J Biol Chem 270:14452-14466

33. Mestyán J, Soltész G, Schultz K, Horváth M 1975 Hyperaminoacidemia due to the accumulation of gluconeogenic amino acid precursors in hypoglycemic small-forgestational age infants. J Pediatr 87:409-414

34. Haymond MW, Karl IE, Pagliara AS 1974 Increased gluconeogenic substrates in the small-for-gestational-age infant. N Engl J Med 291:322-328

35. Stanley CA, Anday EK, Baker L, Delivoria-Papadopolous M 1979 Metabolic fuel and hormone responses to fasting in newborn infants. Pediatrics 64:613-619

36. Williams PR, Fiser RH Jr, Sperling MA, Oh W 1975 Effects of oral alanine feeding on blood glucose, plasma glucagon and insulin concentrations in small-forgestational-age infants. N Engl J Med 292:612-614

37. Marsac C, Saudubray JM, Moncion A, Leroux JP 1976 Development of gluconeogenic enzymes in the liver of human newborns. Biol Neonate 28:317-325

38. Shelley HJ, Neligan GA 1966 Neonatal hypoglycaemia. Br Med Bull 22:34-39

39. Girard J, Ferré P, Pégorier JP, Duée PH 1992 Adaptations of glucose and fatty acid metabolism during perinatal period and suckling-weaning transition. Physiol Rev 72:507-562

40. Devi BG, Habeebullah CM, Gupta PD 1992 Glycogen metabolism during human liver development. Biochem Int 28:229-237

41. Corssmit EPM, Stouthart JML, Romijn JA, Endert E, Sauerwein HP 1994 Sex differences in the adaptation of glucose metabolism to short term fasting: effects of oral contraceptives. Metabolism 43:1503-1508

42. Hume R, Burchell A 1993 Abnormal expression of glucose-6-phophatase in preterm infants. Arch Dis Child 68:202-204

43. Marangou AG, Alford FP, Ward G, Liskaser F, Aitken PM, Weber KM, Boston RC, Best JD 1988 Hormonal effects of norepinephrine on acute glucose disposal in humans: a minimal model analysis. Metabolism 37:885-891

44. Boden G 1997 Role of fatty acids in the pathogenesis of insulin resistance and NIDDM. Diabetes 46:3-10 